OPEN ACCESS

Approved by:

Psychology Editorial Office,

Frontiers, Switzerland

*Correspondence:

Frontiers Production Office production.office@frontiersin.org

$$
\begin{array}{r}
\text { Specialty section: } \\
\text { This article was submitted to } \\
\text { Eating Behavior, } \\
\text { a section of the journal } \\
\text { Frontiers in Psychology }
\end{array}
$$

Received: 22 December 2016 Accepted: 23 December 2016 Published: 27 December 2016

Citation:

Frontiers Production Office (2016) Erratum: Differences in Knowledge, Stress, Sensation Seeking, and Locus

of Control Linked to Dietary Adherence in Hemodialysis Patients.

Front. Psychol. 7:2076. doi: 10.3389/fpsyg.2016.02076

\section{Erratum: Differences in Knowledge, Stress, Sensation Seeking, and Locus of Control Linked to Dietary Adherence in Hemodialysis Patients}

\author{
Frontiers Production Office * \\ Frontiers Production Office, Frontiers, Switzerland
}

Keywords: hemodialysis, adherence, diet, stress, locus of control, personality

\section{An Erratum on}

Differences in Knowledge, Stress, Sensation Seeking, and Locus of Control Linked to Dietary Adherence in Hemodialysis Patients

by Gibson, E. L., Held, I., Khawnekar, D., and Rutherford, P. (2016). Front. Psychol. 7:1864. doi: $10.3389 /$ fpsyg.2016.01864

Reason for Erratum:

Due to a typesetting error, in Table 5, the 2nd column should have been headed "Adherent" instead of "B".

The publisher apologizes for this error and the correct version of the table appears below. This error does not change the scientific conclusions of the article in any way.

TABLE 5 | Comparison of personality traits between adherers and non-adherers for potassium, phosphate, and fluid restrictions (mean $\pm \mathbf{s d}$ ).

\begin{tabular}{lcccccc}
\hline Restriction & Adherent & $\boldsymbol{n}$ & $\begin{array}{c}\text { Sensation seeking } \\
\text { (range 6-24) }\end{array}$ & $\begin{array}{c}\text { Impulsivity } \\
\text { (range 5-20) }\end{array}$ & $\begin{array}{c}\text { Anxiety sensitivity } \\
\text { (range 5-20) }\end{array}$ & $\begin{array}{c}\text { Hopelessness } \\
\text { (range 7-28) }\end{array}$ \\
\hline Potassium & Yes & 23 & $11.0^{*} \pm 3.5$ & $10.1 \pm 3.2$ & $13.8 \pm 2.8$ & $15.0 \pm 3.2$ \\
& No & 15 & $13.5 \pm 3.8$ & $11.3 \pm 2.8$ & $12.9 \pm 1.8$ & $15.3 \pm 4.1$ \\
\hline Phosphate & Yes & 28 & $10.8^{* *} \pm 3.1$ & $10.7 \pm 2.9$ & $13.8 \pm 2.6$ & $14.0 \pm 3.1$ \\
& No & 17 & $13.3 \pm 3.4$ & $11.8 \pm 2.5$ & $13.1 \pm 2.0$ & $16.0 \pm 3.4$ \\
\hline Fluid & Yes & 14 & $9.1^{* *} \pm 2.9$ & $9.4 \pm 2.3$ & $13.3 \pm 3.0$ & $13.9 \pm 3.2$ \\
& No & 25 & $12.2 \pm 3.9$ & $11.4 \pm 3.2$ & $13.6 \pm 2.1$ & $14.4 \pm 3.4$ \\
\hline$* 0<0.05, * *$ \\
$*$
\end{tabular}

Copyright () 2016 Frontiers Production Office. This is an open-access article distributed under the terms of the Creative Commons Attribution License (CC BY). The use, distribution or reproduction in other forums is permitted, provided the original author(s) or licensor are credited and that the original publication in this journal is cited, in accordance with accepted academic practice. No use, distribution or reproduction is permitted which does not comply with these terms. 